\title{
Faktor-faktor yang Berhubungan dengan Waktu Tanggap pada Pelayanan Kasus Kecelakaan Lalu Lintas di Instalasi Gawat Darurat Rumah Sakit Umum Pusat Dr. M. Djamil Padang Tahun 2013
}

\author{
Nailatul Fadhilah ${ }^{1}$, Wirsma Arif Harahap ${ }^{2}$, Yuniar Lestari ${ }^{3}$
}

\begin{abstract}
Abstrak
Penanganan kasus kecelakaan lalu lintas membutuhkan pelayanan yang cepat, tanggap, dan tepat. Salah satu indikator pelayanan tersebut adalah waktu tanggap pada pelayanan pasien di IGD. Penelitian ini dilakukan untuk mengetahui faktor-faktor yang berhubungan dengan waktu tanggap pada pelayanan kasus kecelakaan lalu lintas di IGD RSUP Dr. M. Djamil Padang. Penelitian ini dilaksanakan dari bulan Mei hingga Desember 2013 di IGD RSUP Dr. M. Djamil dengan desain penelitian studi cross-sectional. Pengambilan data menggunakan lembaran observasi dan diberikan kepada 60 orang pasien kecelakaan lalu lintas yang dipilih secara acak. Data dianalisis secara univariat dan bivariat menggunakan uji silang dengan tingkat kemaknaan $p=0,05$. Hasil penelitian menunjukkan $70 \%$ memiliki waktu tanggap yang tepat, dimana rata-rata waktu tanggap adalah 6 menit 15 detik. Sebagian besar pasien kecelakaan lalu lintas berada dalam keadaan gawat tidak darurat atau triase kuning (80\%). Pada sebagian besar kasus petugas berada di meja triase saat pasien datang (86,67\%). Sebagian besar pasien dibawa ke triase dari pintu masuk IGD dengan brankar (86,67\%). Tidak terdapat hubungan yang signifikan antara tingkat kegawatan pasien, keberadaan petugas yang bersiaga di triase, dan ketersediaan brankar dengan ketepatan waktu tanggap.
\end{abstract}

Kata kunci: waktu tanggap, faktor-faktor yang berhubungan, kecelakaan lalu lintas, IGD

\section{Abstract}

Traffic accident cases management requires prompt, responsive, and precise service. Time response is one of several indicators of ER patient service. The aim of this study is to observe the factors that related to time response of traffic accident case management in Emergency Department of Dr. M. Djamil Hospital, Padang. This cross-sectional study was conducted between May and December 2013 by using observational sheet which is distributed to 60 randomly chosen from traffic accident patients in Dr. M. Djamil General Hospital. Crosstab analysis was used to determine the difference among variables. Chi-square test was used to determine the significance of categorical variables. Data were analyzed using univariate and bivariate cross test with a significance level of $p=0.05$. Result showed that out of 60 cases, $70 \%$ cases had accurate response time. The average response time is 6 minutes 15 seconds. Most of traffic accident patients are in a yellow triage (80\%). In most cases, 86,67\% officers are at the triage desk. Most of the patients brought to the triage from the emergency department entrance by stretchers (86.67\%). There was no significant relationship between the level of patient severity, payment method, the availability of stretchers when patients come and response time $(p>0,05)$. Analysis of the relationship between the presence of officers and response time cannot be performed. The presence of officers in triage when patient arrived tended to speed up the response time.

Keywords: response time, related factors, traffic accident, emergency room

\begin{tabular}{lll}
\hline Affiliasi penulis : 1. Pendidikan Dokter FK UNAND (Fakultas & Korespondensi : Nailatul Fadhilah, E-mail: ffdhilaworld@yahoo.com, \\
Kedokteran Universitas Andalas, 2. Bagian Bedah FK UNAND, & Telp: 085274209023
\end{tabular}
3.Bagian IImu Kesehatan Masyarakat FK UNAND 


\section{PENDAHULUAN}

Kecelakaan adalah suatu kejadian dimana terjadi interaksi berbagai faktor yang datangnya mendadak dan tidak dikehendaki, sehingga menimbulkan cedera fisik, mental, dan sosial. Kecelakaan dan cedera dapat diklasifikasikan menurut tempat kejadian, salah satunya adalah kecelakaan lalu lintas Menurut Peraturan Pemerintah RI No. 43 tahun 1993, kecelakaan lalu lintas adalah suatu peristiwa di jalan yang tidak disangka-sangka dan tidak disengaja melibatkan kendaraan dengan atau tanpa pemakai jalan lainnya, mengakibatkan korban manusia atau kerugian harta benda. ${ }^{1,2}$

Kecelakaan lalu lintas adalah penyebab utama kematian, yang telah menyebabkan hampir 1,3 juta orang meninggal setiap tahunnya. Di Indonesia, menurut laporan Koordinator Lalu Lintas Kepolisian RI, di tahun 2010 tercatat 104.824 kasus kecelakaan lalu lintas telah terjadi di Indonesia. Provinsi Sumatera Barat menduduki urutan ke 11 dari 31 provinsi di Indonesia yang memiliki kasus kecelakaan lalu lintas terbanyak (2.651 kasus), dengan korban meninggal 749 orang, luka berat 1.679 orang, dan luka ringan 2.277 orang. Di Padang, kecelakaan berada di urutan ke-6 penyebab kematian terbanyak di kota Padang tahun 2011 dengan jumlah 30 kasus $(6,6 \%){ }^{3-5}$

Dari data rekam medis RSUP Dr. M. Djamil tahun 2012 tercatat pasien IGD untuk triage Bedah (surgikal) berjumlah 4.262 dari 37.124 kunjungan IGD secara keseluruhan $(11,4 \%)$, di mana diantara pasien tersebut adalah korban kasus kecelakaan lalu lintas. Serta jumlah mortalitas pasien secara keseluruhan berjumlah 298 pasien (0,8\%). Data lain dari RSUD Cengkareng dari Januari - September 2011, tercatat angka kecelakaan lalu lintas berjumlah 521 dari 15.186 kunjungan IGD seluruhnya (3,4\%). Jumlah kematian dari kasus kecelakaan lalu lintas sebanyak 22 orang $(4,2 \%)$ dan 6 diantaranya adalah D.O.A (Death On Arrival). ${ }^{6}$

Korban kecelakaan lalu lintas yang mengalami luka ringan biasanya langsung ditangani secara medis sesuai dengan perlukaan yang diderita. Sedangkan korban meninggal dapat langsung diselesaikan berkas perkaranya dan dapat langsung diserahkan kepada keluarga. Tidak jarang korban kecelakaan lalu lintas yang jatuh ke dalam kondisi gawat darurat, di mana korban gawat darurat adalah korban yang terancam jiwanya dan harus segera ditangani dan dibawa ke pelayanan gawat darurat. ${ }^{7}$

Pelayanan pasien gawat darurat adalah pelayanan yang memerlukan pertolongan segera yaitu cepat, tepat dan cermat untuk mencegah kematian dan kecacatan, atau pelayanan pasien gawat darurat memegang peranan yang sangat penting bahwa waktu adalah nyawa (Time saving is life saving). Salah satu indikator mutu pelayanan berupa respon time atau waktu tanggap yang merupakan indikator proses untuk mencapai indikator hasil, yaitu kelangsungan hidup. $^{8}$

Prinsip umum mengenai pelayanan di IGD tercantum dalam Kepmenkes RI nomor 856 tahun 2009 mengenai Standar IGD di Rumah Sakit, yang berbunyi:" Pasien gawat darurat harus ditangani paling lama 5 (lima) menit setelah sampai di IGD”. Pelayanan gawat darurat harus sesuai dengan waktu tanggap yang cepat dan penanganan yang tepat. Semua itu dapat dicapai antara lain dengan meningkatkan sarana, prasarana, sumber daya manusia dan manajemen Instalasi Gawat Darurat Rumah Sakit sesuai dengan standar. ${ }^{9}$

Menurut Kepmenkes nomor 129 tahun 2008 mengenai Standar Pelayanan Minimal Rumah Sakit (SPM-RS), waktu tanggap pelayanan dokter di gawat darurat memiliki dimensi mutu keselamatan dan efektifitas. Kecepatan pelayanan dokter di gawat darurat adalah kecepatan pasien dilayani sejak pasien datang sampai mendapat pelayanan dokter (menit).Waktu tanggap tersebut memiliki standar maksimal 5 menit di tiap kasus. Waktu tanggap pelayanan perlu diperhitungkan agar terselenggaranya pelayanan yang cepat, responsif dan mampu menyelamatkan pasien gawat darurat. ${ }^{10}$

Penelitian sebelumnya yang dilakukan di RSUP Dr. Wahidin Sudirohusodo menyatakan bahwa faktor-faktor yang mempengaruhi waktu tanggap di IGD Bedah adalah ketersediaan stretcher dan ketersediaan petugas triase. Dari observasi penelitian tersebut tercatat waktu tanggap penanganan kasus IGD bedah yang tepat sebanyak $67,9 \%$ dan tidak tepat sebanyak $32,1 \%{ }^{11}$

Meskipun penelitian tentang waktu tanggap pelayanan IGD telah dilakukan di berbagai negara, 
faktor-faktor yang berhubungan dengan waktu tanggap belum sepenuhnya dapat dimengerti.Hal ini disebabkan oleh masih terbatasnya penelitian yang mengangkat isu tersebut.

Penelitian ini dilakukan untuk mengetahui faktor-faktor yang berhubungan dengan waktu tanggap pada pelayanan kasus kecelakaan lalu lintas di IGD RSUP Dr. M. Djamil Padang tahun 2013.

\section{METODE}

Penelitian ini dilakukan di IGD RSUP Dr. M. Djamil Padang pada bulan Juni sampai Juli 2013.Sampel pada penelitian ini adalah pasien kecelakaan lalu lintas. Penelitian ini menggunakan desain studi cross-sectional, menggunakan lembaran observasi yang diberikan kepada 60 orang pasien kecelakaan lalu lintas yang dipilih secara acak. Data dianalisis secara univariat dan bivariat menggunakan uji silang dengan tingkat kemaknaan $p=0,05 .{ }^{12}$ Variabel dependennya adalah waktu tanggap, sedangkan variabel independennya adalah faktor pasien (tingkat kegawatan), faktor petugas (keberadaan petugas), faktor biaya (cara bayar), dan faktor ketersediaan alat (brankar).

\section{HASIL}

Tabel 1. Distribusi Frekuensi Karakteristik Pasien Pasien Kecelakaan Lalu Lintas di IGD RSUP Dr. M. Djamil

\begin{tabular}{clcc}
\hline No. & Karakteristik Pasien & Frekuensi & $\%$ \\
\hline 1. & Usia & 1 & 1,67 \\
& $1-4$ & 8 & 13,33 \\
& $5-14$ & 25 & 41,67 \\
& $15-24$ & 14 & 23,22 \\
& $25-44$ & 11 & 18,33 \\
& $45-64$ & 1 & 1,67 \\
& $\geq 65$ & & \\
\hline 2. & Jenis Kelamin & 38 & 63,33 \\
& Laki-laki & 22 & 36,67 \\
\hline & Perempuan & & \\
\hline 3. & Cara Datang & 16 & 26,67 \\
& Datang sendiri & 9 & 15 \\
& Dengan angkutan & & \\
& umum & 35 & 58,33 \\
& Dengan ambulans & 0 & 0 \\
\hline & Dengan mobil polisi & & \\
\hline 4. & Petugas yang & & \\
& Melayani Pertama Kali & &
\end{tabular}

\begin{tabular}{lll} 
Dokter & 14 & 23,33 \\
Perawat & 23 & 38,33 \\
Dokter muda/ & 23 & 38,33 \\
mahasiswa & & \\
keperawatan & & \\
\hline \multicolumn{1}{c}{ Total } & $\mathbf{6 0}$ & $\mathbf{1 0 0}$ \\
\hline
\end{tabular}

Pada tabel 1 diterangkan bahwa usia pasien bervariasi antara umur 3 sampai 66 tahun. Kelompok usia terbanyak adalah 15-24 tahun sebanyak 25 orang (41,67\%), disusul dengan kelompok usia 25-44 tahun sebanyak 14 orang $(23,22 \%)$.

Sebagian besar pasien kecelakaan lalu lintas dalam penelitian ini berjenis kelamin laki-laki, yakni sebanyak 38 orang $(63,33 \%)$, sementara 22 orang $(36,67 \%)$ sisanya adalah pasien perempuan. Cara datang pasien yang dilihat dalam penelitian ini antara lain datang sendiri, datang dengan menggunakan mobil angkutan umum, datang dengan menggunakan mobil ambulans, dan datang dengan menggunakan mobil polisi. Cara datang yang terbanyak adalah dengan menggunakan mobil ambulans, yaitu sebanyak 35 pasien (58,33\%). Disusul dengan pasien yang datang sendiri sebanyak 16 pasien (26,67\%). Pasien yang dilayani pertama kali oleh perawat memiliki proporsi yang sama banyak dengan pasien yang dilayani oleh dokter muda/mahasiswa keperawatan, yaitu sebanyak 23 pasien (38,33\%). Pasien yang dilayani pertama kali oleh dokter memiliki jumlah yang lebih sedikit, yaitu sebanyak 14 pasien $(23,33 \%)$.

Tabel 2. Distribusi Frekuensi Ketepatan Waktu Tanggap Pelayanan Pasien Kecelakaan Lalu Lintas di IGD RSUP Dr. M. Djamil Padang

\begin{tabular}{cccc}
\hline No. & Waktu Tanggap & Frekuensi & $\%$ \\
\hline 1. & Tepat & 42 & 70 \\
2. & Tidak tepat & 18 & 30 \\
\hline & Total & $\mathbf{6 0}$ & $\mathbf{1 0 0}$ \\
\hline
\end{tabular}

Tabel 2 menerangkan bahwa sebanyak 42 (70\%) pasien memiliki waktu tanggap yang tepat, sedangkan 18 (30\%) pasien lainnya memiliki waktu tanggap yang tidak tepat. Waktu tanggap yang paling cepat adalah 25 detik dan yang paling lama memakan waktu 72 menit. Rata-rata waktu tanggap dalam 
penelitian ini adalah 6 menit 15 detik, dengan nilai standar deviasi 10 menit 36 detik. Median dari waktu tanggap dalam penelitian ini adalah 3 menit 2 detik.

Terlihat dalam tabel 3 , tingkat kegawatan pasien kecelakaan lalu lintas yang memiliki proporsi terbanyak adalah kelompok pasien gawat tidak darurat (kuning), yaitu sebanyak 48 pasien (80\%). Tingkat kegawatan yang memiliki proporsi tersedikit dimiliki oleh kelompok pasien tidak gawat tidak darurat (hijau), yaitu 5 pasien $(8,33 \%)$.

Kasus dimana petugas triase ada di triase pada saat kedatangan pasien berjumlah 56 (93,33\%) kasus, seperti yang tercantum pada tabel 3 . Sementara pada $4(6,67 \%)$ kasus lainnya petugas triase tidak berada di triase pada saat kedatangan pasien.

Tabel 3. Distribusi Frekuensi Variabel Independen (Faktor-Faktor) Pada Pelayanan Pasien Kecelakaan Lalu Lintas di IGD RSUP Dr. M. Djamil Padang

\begin{tabular}{lcc}
\hline \multicolumn{1}{c}{ Faktor-faktor } & Frekuensi & $\%$ \\
\hline Tingkat kegawatan pasien & 7 & 11,67 \\
Merah & 48 & 80 \\
Kuning & 5 & 8,33 \\
Hijau & & \\
\hline Keberadaan Petugas & 52 & 86,67 \\
Ada & 8 & 13,33 \\
Tidak ada & & \\
\hline Cara Bayar & 35 & 58,33 \\
Biaya sendiri & 25 & 41,67 \\
Asuransi & 15 & 25,00 \\
a. Jamkesmas & 3 & 5,00 \\
b. Jamkesda & 5 & 8,33 \\
c. Askes & 0 & 0 \\
d. Asuransi lainnya & 2 & 3,33 \\
e. Ikatan Kerja Sama & & \\
\hline Ketersediaan Brankar & 52 & 86,67 \\
Tersedia & 60 & 13,33 \\
Tak Tersedia & 100 \\
\hline Total & & \\
\hline
\end{tabular}

Cara bayar yang paling banyak digunakan oleh pasien kecelakaan lalu lintas adalah dengan biaya sendiri, yaitu sebanyak 35 (66,04\%) pasien. Jamkesmas digunakan oleh 15 (28,30\%) pasien yang merupakan cara bayar terbanyak kedua. Tidak ada pasien yang menggunakan asuransi lainnya sebagai pembayaran pelayanan IGD pada penelitian ini.Selengkapnya tercantum di dalam tabel 3.

Tabel 3 juga menerangkan bahwa sebanyak $52(86,67 \%)$ pasien kecelakaan lalu lintas dibawa ke triase menggunakan brankar. Sementara 8 (13,33\%). pasien lainnya tidak menggunakan brankar atau brankar tidak tersedia saat pasien datang.

Dari tabel 4 terlihat bahwa persentase waktu tanggap tidak tepat lebih tinggi pada tingkat kegawatan Kuning dibandingkan waktu tanggap dengan tingkat kegawatan Merah dan Hijau. Berdasarkan uji chi-square diperoleh $p=0,878$ ( $p>$ $0,05)$, yang berarti tidak ada hubungan antara tingkat kegawatan dengan waktu tanggap.Pasien yang memiliki pelayanan yang tidak tepat seluruhnya datang saat petugas tidak berada di triase (100\%). Namun, uji chi-square tidak dapat dilakukan karena

Tabel 4. Uji Silang Variabel Independen (FaktorFaktor) Dengan Waktu Tanggap Pasien Kecelakaan Lalu Lintas di IGD RSUP Dr. M. Djamil Padang.

\begin{tabular}{|c|c|c|c|c|c|c|c|}
\hline \multirow{3}{*}{$\begin{array}{l}\text { Faktor- } \\
\text { faktor }\end{array}$} & \multicolumn{6}{|c|}{ Waktu Tanggap } & \multirow{3}{*}{$p$} \\
\hline & \multicolumn{2}{|c|}{$\begin{array}{l}\text { Tidak } \\
\text { Tepat }\end{array}$} & \multicolumn{2}{|c|}{ Tepat } & \multicolumn{2}{|c|}{ Jumlah } & \\
\hline & $f$ & $\%$ & $f$ & $\%$ & $f$ & $\%$ & \\
\hline Tingkat & & & & & & & 0,878 \\
\hline \multicolumn{8}{|l|}{ Kegawata } \\
\hline \multicolumn{8}{|l|}{$\mathbf{n}$} \\
\hline Merah & 2 & 28,6 & 5 & 71,4 & 7 & 100 & \\
\hline Kuning & 14 & 29,2 & 34 & 70,8 & 48 & 100 & \\
\hline Hijau & 2 & 40 & 3 & 60 & 5 & 100 & \\
\hline $\begin{array}{l}\text { Kebera- } \\
\text { daan }\end{array}$ & & & & & & & - \\
\hline \multicolumn{8}{|l|}{ Petugas } \\
\hline Tidak Ada & 8 & 100 & 0 & 0 & 8 & 100 & \\
\hline Ada & 10 & 19,2 & 42 & 80,8 & 52 & 100 & \\
\hline Cara & & & & & & & 0,569 \\
\hline \multicolumn{8}{|l|}{ Bayar } \\
\hline \multicolumn{8}{|l|}{ Biaya } \\
\hline Sendiri & 12 & 34,3 & 23 & 65,7 & 35 & 100 & \\
\hline Asuransi & 6 & 24 & 19 & 76 & 25 & 100 & \\
\hline $\begin{array}{l}\text { Keterse- } \\
\text { diaan }\end{array}$ & & & & & & & 0,225 \\
\hline \multicolumn{8}{|l|}{ Brankar } \\
\hline \multicolumn{8}{|l|}{ Tak } \\
\hline tersedia & 4 & 50 & 4 & 50 & 8 & 100 & \\
\hline Tersedia & 14 & 26,9 & 38 & 73,1 & 52 & 100 & \\
\hline
\end{tabular}

terdapat sel yang kosong. Persentase waktu tanggap tidak tepat lebih tinggi pada cara bayar dengan biaya sendiri dibandingkan cara bayar dengan 
menggunakan asuransi. Berdasarkan uji chi-square diperoleh $p=0,569$ ( $p>0,05)$, yang berarti tidak ada hubungan antara cara bayar dengan waktu tanggap. Persentase waktu tanggap tidak tepat lebih tinggi pada kasus yang brankar tak tersedia saat pasien datang atau pasien tidak menggunakan brankar saat masuk ke IGD dibandingkan waktu tanggap pada kasus dimana brankar tersedia saat pasien datang. Berdasarkan uji Fisher (alternatif dari uji chi-square) diperoleh $p=0,225(p>0,05)$, yang berarti tidak ada hubungan antara ketersediaan brankar dengan waktu tanggap.

\section{PEMBAHASAN}

Menurut Kepmenkes nomor 129 tahun 2008 tentang Standar Pelayanan Minimal Rumah Sakit (SPM-RS), waktu tanggap pelayanan dokter di instalasi gawat darurat memiliki standar maksimal 5 menit di tiap kasus. Dari hasil penelitian menunjukkan bahwa lebih dari separuh jumlah pasien kecelakaan memiliki waktu tanggap yang tepat (70\%). Namun demikian, hasil rerata waktu tanggap menunjukkan nilai yang lebih tinggi dari standar, yaitu 6 menit 15 detik. Penelitian lain yang serupa yang dilakukan oleh Sabriyanti dkk pada tahun 2012 di IGD RSUP Dr. Wahidin Sudirohusodo menunjukkan waktu tanggap untuk penanganan kasus bedah lebih dari separuhnya adalah tepat $(67,9 \%) .{ }^{11}$

Penyebab ketidaktepatan waktu tanggap ini diasumsikan berasal dari sistem registrasi pasien yang dimiliki. Karena menurut alur registrasi pasien di IGD tempat penelitian dilakukan, registrasi pasien dilakukan sebelum pasien diseleksi tingkat kegawatannya oleh dokter yang bertugas. Hal ini mengakibatkan waktu tanggap pasien menjadi lebih panjang. Meskipun demikian, ada pasien yang tetap ditanggapi oleh petugas walaupun belum melakukan registrasi, seperti pasien dengan kondisi terancam nyawa setibanya di IGD. Kondisi IGD yang dipenuhi oleh pasien menyebabkan dokter kewalahan memberi penanganan secara cepat dan efisien kepada pasien. Di beberapa kasus, pasien kecelakaan tertunda mendapatkan tanggapan dari dokter yang berjaga karena adanya pasien lain yang bukan korban kecelakaan lalu lintas yang datang secara bersamaan dengan kondisi lebih gawat. Secara keseluruhan, waktu tanggap pelayanan pasien kecelakaan lalu lintas di IGD RSUP Dr. M. Djamil sudah baik, terlihat dari pasien yang memiliki waktu tanggap yang tepat lebih banyak dibandingkan yang tidak tepat.

Pada penelitian ini, persentase waktu tanggap tidak tepat lebih tinggi pada tingkat kegawatan Kuning dibandingkan waktu tanggap dengan tingkat kegawatan Merah dan Hijau. Berdasarkan uji chi-square diperoleh $p=0,878(p>$ $0,05)$, yang berarti tidak ada hubungan antara tingkat kegawatan dengan waktu tanggap. Kemungkinan hal tersebut disebabkan oleh tidak meratanya penyebaran tingkat kegawatan pasien dalam penelitian ini, dimana lebih dari separuh jumlah pasien masuk ke dalam kategori gawat tidak darurat (kuning). Hal ini kemungkinan dikarenakan adanya perbedaan prinsip untuk penentuan kategori tingkat kegawatan pasien pada petugas tersebut. Penelitian sebelumnya yang dilakukan oleh Yoon dkk ditahun 2003, dimana pasien yang memiliki tingkat kegawatan yang tertinggi (Level I) memiliki waktu tanggap yang cepat, sedangkan tingkat kegawatan yang lebih rendah (Level IV dan V) waktu tanggap menjadi lebih lama. ${ }^{13}$ Sehingga, masih ada asumsi bahwa tingkat kegawatan tetap menjadi faktor yang berhubungan dengan waktu tanggap, walaupun hubungan tersebut tidak secara langsung terjadi karena berbagai kondisi yang terjadi di IGD.

Dari tabel 4 terlihat bahwa pasien yang memiliki pelayanan yang tidak tepat seluruhnya datang saat petugas tidak berada di triase (100\%).Analisis hubungan tidak bisa dilakukan antara keberadaan petugas dengan waktu tanggap karena terdapat sel yang kosong.Sehingga, hasil ini tidak bisa dibandingkan dengan studi serupa yang telah dilakukan di RSUP Dr. Wahidin Sudirohusodo. Penelitian tersebut menyatakan bahwa terdapat hubungan yang signifikan antara keberadaan petugas di meja triase dengan waktu tanggap untuk kasus IGD Bedah dengan nilai $p=0,006$, yang berarti penanganan kasus di mana dokter dan perawat triase berada di meja triase untuk menerima pasien baru memiliki hubungan dengan ketepatan waktu tanggap. ${ }^{11}$ Sehingga, peneliti beranggapan masih ada kecendrungan petugas, dalam hal ini dokter jaga, yang 
bersiaga di triase saat kedatangan pasien kecelakaan lalu lintas dapat mempercepat waktu tanggap pasien tersebut.

Tabel 4 menunjukkan bahwa tidak terdapat hubungan antara cara bayar dengan waktu tanggap pasien kecelakaan lalu lintas $(p=0,569)$. Didapatkan kasus antara cara bayar sendiri dengan cara bayar dengan menggunakan asuransi (Jamkesmas, Jamkesda, Askes, dan Ikatan Kerja Sama) keduanya memiliki jumlah waktu tanggap yang tepat lebih banyak dibandingkan jumlah waktu tanggap yang tidak tepat. Sehingga, dapat disimpulkan bahwa tidak terdapat perbedaan pelayanan antara pasien yang menggunakan jasa asuransi dengan pasien yang menggunakan biaya sendiri saat ditangani di IGD. Sampai saat ini, peneliti masih belum menemukan penelitian lain yang meneliti hubungan antara cara bayar pasien dengan waktu tanggap pelayanan di IGD.

Tidak terdapat hubungan yang signifikan antara ketersediaan brankar dengan waktu tanggap pasien kecelakaan di IGD ( $p=0,225)$. Pasien yang dipapah atau digendong dimasukkan ke dalam kasus ketidaktersediaan brankar,karena pasien pun juga membutuhkan brankar sebagai tempat tidurnya ketika ditangani oleh petugas di triase.Data selengkapnya terlampir. Hasil penelitian ini berbeda dengan penelitian yang dilakukan di RSUP Dr. Wahidin Sudirohusodo dimana penelitian tersebut menyatakan ada hubungan yang erat antara ketersediaan brankar dengan waktu tanggap di IGD Bedah $(p=0,006) .{ }^{11}$ Brankar merupakan tempat tidur dorong yang digunakan untuk mempermudah mobilisasi pasien dari pintu IGD sampai akhirnya dipulangkan. Pasien yang dijemput dengan brankar di pintu IGD tidak menjamin waktu tanggap akan cepat, tapi lebih kepada keefisienan waktu yang dibutuhkan pasien untuk sampai ke triase. Pasien juga dibawa dengan kecepatan yang berbeda-beda di setiap pasiennya.Peneliti beranggapan masih ada hubungan antara ketersediaan brankar dengan waktu tanggap, namun dalam penelitian ini tampaknya tidak begitu signifikan karena walaupun pasien langsung mendapatkan brankar saat masuk ke IGD, mereka masih harus menunggu dokter terlebih dahulu.

\section{KESIMPULAN}

Tidak terdapat hubungan yang signifikan antara tingkat kegawatan pasien, keberadaan petugas yang bersiaga di triase, dan ketersediaan brankar dengan ketepatan waktu tanggap. Analisis hubungan antara keberadaan petugas dan ketepatan waktu tanggap tidak dapat dilakukan. Perlu penelitian lebih lanjut mengenai pengetahuan dan keterampilan petugas IGD.

\section{Keterbatasan Penelitian}

Keterbatasan dalam penelitian ini adalah sampel yang digunakan masih sedikit karena keterbatasan waktu yang dimiliki oleh peneliti.Waktu pengambilan data yang beragam sehingga data korban kecelakaan yang didapatkan kurang maksimal.Penelitian ini dilakukan dengan observasi oleh peneliti sendiri langsung di lapangan, sehingga sedikit menyulitkan bila pasien datang dengan jumlah banyak dalam waktu yang bersamaan. Diharapkan pada penelitian selanjutnya pengambilan data dilakukan selama 24 jam penuh agar sebaran data lebih baik dan lebih mewakili sampel dan dapat membentuk sebuah tim dalam pencatatan waktu tanggap pelayanan IGD. Serta diharapkan dalam penelitian selanjutnya dapat meneliti waktu tanggap dalam keseluruhan kasus, sehingga didapatkan hasil yang dapat mewakili waktu tanggap pelayanan pasien yang berobat ke IGD.

\section{DAFTAR PUSTAKA}

1. Departemen Kesehatan RI. Pedoman pelayanan gawat darurat. Jakarta; 1995

2. Peraturan Pemerintah RI Nomor 43 Tahun 1993 Prasarana dan Lalu Lintas Jalan. 14 Juli 1993. Lembaran Negara Republik Indonesia Tahun 1993 Nomor 60. Jakarta; 1993.

3. WHO. $2^{\text {nd }}$ second global status report on road safety; 2011. (diunduh11 Desember 2011). Tersedia dari: URL: HYPERLINK http://www.who.int.

4. Kementrian Kesehatan RI. Profil data kesehatan Indonesia tahun 2011. Jakarta; 2012.

5. Dinas Kesehatan Kota Padang. Laporan tahunan tahun 2011. Padang; 2012 
6. RSUD Cengkareng. Laporan kerja instalasi gawat darurat RSUD Cengkareng September 2011. Jakarta : RSUD Cengkareng; 2011.

7. Adriliananda, LM. Hubungan faktor kecepatan dan kualitas pertolongan pertama terhadap keadaan korban kecelakaan lalu lintas daerah operasional PMI Jakarta Pusat Tahun 2009-2010 (skripsi). Universitas Pembangunan Nasional "Veteran", Jakarta; 2011.

8. Haryatun N, Sudaryanto A. Perbedaan waktu tanggap tindakan keperawatan pasien cedera kepala kategori I-V di Instalasi Gawat Darurat RSUD Dr. Moewardi. Berita IImu Keperawatan. 2008; 1(2):69-74.

9. Keputusan Menteri Kesehatan Republik Indonesia Nomor 856 tahun 2009 Standar Instalasi Gawat
Darurat (IGD) Rumah Sakit. Jakarta; 2009.

10. Keputusan Menteri Kesehatan Republik Indonesia Nomor 129 tahun 2008 Standar Pelayanan Minimal Rumah Sakit. Jakarta; 2008.

11. Sabriyanti W, et al. Faktor-faktor yang berhubungan dengan ketepatan waktu tanggap penanganan kasus pada response time di instalasi gawat darurat bedah dan non-bedah RSUP Dr. Wahidin Sudirohusodo (tesis).Makassar: Universitas Hasanuddin; 2012.

12. Notoatmodjo S. Metodologi penelitian kesehatan. Jakarta: PT Rineka Cipta; 2010.

13. Yoon P, Steiner I, Reinhardt G. Analysis of factors influencing length of stay in the emergency department. Canadian Journal of Emergency Medicine. 2003; 5(3):155-61. 